\title{
The Effect of Market Experience on the WTA/WTP Disparity: Evidence from a Field Experiment with Sports Memorabilia
}

\author{
John A. List* \\ Associate Professor \\ University of Arizona
}

11 April 2000

\begin{abstract}
A bulk of recent evidence suggests that important disparities exist between willingness to pay and compensation demanded for the same good. This paper extends and refutes the generality of these findings by going to a well-functioning marketplace and allowing consumers to swap sports memorabilia. In support of the received literature, I present field evidence that suggests an inefficiently low number of trades occur for naïve traders, suggesting referencedependent preferences. In contrast, this anomaly is not evident for consumers that have significant trading experience. These results uncover important successes and failures of the theoretical literature, and provide challenges for both neoclassical and reference-dependent theorists.
\end{abstract}

JEL: Q21, Q26

Key words: WTP/WTA disparity, field experiment, experience

Current correspondence:

Correspondence after August 2000:

John A. List

College of Business Building

John A. List

University of Central Florida

Economics Building, Room 319

Orlando, FL 32816-1400

e-mail: John.List@bus.ucf.edu

1110 E. North Campus Drive

The University of Arizona

Tucson, Arizona 85721-0023

This paper can be downloaded from the

Social Science Research Network Electronic Paper Collection:

http://papers.ssrn.com/paper.taf?abstract_id $=230007$

\footnotetext{
*I would like to thank Colin Camerer and Bob Deacon for insightful discussion of the important issues. Shelby Gerking, Jeffrey Racine, Mark Strazicich, John Swinton, and Aart de Zeeuw provided constructive remarks on an earlier version of the paper. Seminar participants at Yale University, University of Arizona, and the University of South Florida also provided useful comments.
} 


\title{
The Effect of Market Experience on the WTA/WTP Disparity: Evidence from a Field Experiment with Sports Memorabilia
}

11 April 2000

\begin{abstract}
A bulk of recent evidence suggests that important disparities exist between willingness to pay and compensation demanded for the same good. This paper extends and refutes the generality of these findings by going to a well-functioning marketplace and allowing consumers to swap sports memorabilia. In support of the received literature, I present field evidence that suggests an inefficiently low number of trades occur for naïve traders, suggesting referencedependent preferences. In contrast, this anomaly is not evident for consumers that have significant trading experience. These results uncover important successes and failures of the theoretical literature, and provide challenges for both neoclassical and reference-dependent theorists.
\end{abstract}

JEL: Q21, Q26

Key words: WTP/WTA disparity, field experiment, experience 
Economic theory suggests that with small income effects and many available substitutes, the willingness to pay (WTP) for a commodity and the willingness to accept (WTA) compensation to sell the same commodity should be about equal (Robert Willig, 1976; Alan Randall and John R. Stoll, 1980; W. Michael Hanemann, 1991). But in an influential experimental study using a discrete-choice auction to buy and sell commodities with close substitutes (pens and coffee mugs), Daniel Kahneman et al. (1990) provide evidence to reject the WTA/WTP equality hypothesis. ${ }^{1}$ These experimental findings have been robust across neoteric goods, such as irradiated sandwiches, and common goods, such as chocolate bars, with most authors noting that the deviation between WTP and WTA is much larger than economic intuition would suggest. $^{2}$

Although a chiliad of theories have been advanced to explain the anomaly, including value (or preference) uncertainty (e.g., Ronald A. Heiner, 1983), substitution effects (e.g., Hanemann, 1991), and regret theory (e.g., Graham Loomes and Robert Sugden, 1982), perhaps the most accepted conjecture is that preferences are referencedependent (e.g., Daniel Kahneman and Amos Tversky, 1979; Tversky and Kahneman, 1991). ${ }^{3}$ If consumers have reference-dependent preferences, implications are substantial

\footnotetext{
${ }^{1}$ Early evidence of the disparity was found in contingent valuation (CV) studies (see, e.g., David Brookshire et al., 1980). A review of the data issues associated with CV studies is presented in John A. List and Jason F. Shogren (1998b).

${ }^{2}$ For a good survey of the literature, see John Horowitz and K.E. McConnell (1998). There are exceptions to this general finding. One notable study is Jason F. Shogren et al. (1994), who observe no significant difference between WTP and WTA for candy bars and coffee mugs in a Vickrey $2^{\text {nd }}$ price auction with repeated market experience. This result is refuted, however, in Knetsch et al. (1998), who argue that this finding is an artifact of the Vickrey $2^{\text {nd }}$ price auction institution.

${ }^{3}$ Richard Thaler (1980) first coined the term endowment effect, which implies that a good's value increases once it becomes part of an individual's endowment. The interested reader should see Elizabeth Hoffman and Matthew Spitzer (1993), who provide a nice explanation of competing theories and provide insightful discussion of why the value disparity is important.
} 
in both a positive and normative sense. From a positive perspective, the disparity between WTA and WTP essentially renders the invariance result of Coase invalid. In a normative sense, reference-dependent preferences call into question commonly held interpretations of indifference curves, make cost/benefit analysis illegitimate, and change the procedure necessary to resolve damage disputes.

Given the notable significance of the reference-dependent anomaly, it is important to understand if the WTA/WTP disparity is robust to alternative realistic scenarios. My personal experience in the sportscard market calls into question the robustness of the endowment effect. In my early days as a sportscard dealer, I could sense an apprehension in making trades with other dealers and ordinary consumers whilst more experienced dealers readily snapped up sportscards and other pieces of sports memorabilia in exchange for their own goods. As my own trading experience intensified, I became immune to this (seemingly irrational) notion of bypassing beneficial trades. Within a few months, I had developed a sense of trading experience that increased my volume of trades more than five-fold from their previous levels, increasing my profits and paying my tuition for an undergraduate economics degree. In essence, I had learned to effectively trade, and any notion of an endowment effect was purely inconsequential. If this sort of experience is common, the persistent value disparities observed in the literature may be an artifact of the lack of marketlike experience, not due to a fundamental shortcoming of neoclassical theory.

In this paper, I gather primary data from a sportscard market to test whether my own experience was an anomaly. My data gathering approach is unique in that I examine trading patterns of sports memorabilia on the floor of a sportscard show. A sportscard 
trading show is a natural setting for an experiment on the relationship between trading experience and the endowment effect, as it allows subjects of all ages and experience levels to participate. In this set of experiments, I conduct some of the treatments with professional card and memorabilia dealers and others with ordinary consumers. The design was used to capture the distinction between those consumers that have intense trading experience (dealers) and those that have less trading experience (nondealers).

The main results of the study fall into two categories. First, consistent with previous studies, I observe a significant endowment effect in the pooled data. Although neoclassical theory predicts that $50 \%$ of subjects should trade their endowed piece of sports memorabilia for another piece of sports memorabilia, I find that less than $34 \%$ actually traded. However, I find strong evidence that suggests trading experience matters. Across all consumer types, intensity of trading experience and the magnitude of the endowment effect are negatively related. In addition, within the group of subjects that had intense trading experience (sportscard dealers and experienced nondealers), I find that the endowment effect essentially disappears.

\section{Experimental Design}

If a fundamental endowment effect exists, it should prevail regardless of the level of subject experience. Some researchers have conjectured that the disparity is a mistake, and will disappear if subjects gain experience. If this premise is correct, the data should show signs of an inverse relationship between experience and the level of the endowment

effect. Alternatively, if the endowment effect is not a mistake, but a fundamental component of agents' underlying preferences, experience and the endowment effect should be orthogonal. Primarily using repeated trials in a competitive setting, some 
laboratory studies have presented evidence that suggests experience and the level of the endowment effect are related (Peter Knez et al., 1985; Don Coursey et al., 1987; David Brookshire and Don Coursey, 1987; Shogren et al., 1994). Critics contend that at best the evidence is mixed, and overall the data do not conclusively support the underlying premise (Jack Knetsch and J.A. Sinden, 1987; Knetsch et al., 1998). Furthermore, as Colin Camerer and Robin Hogarth (1999) note, useful cognitive capital builds up slowly, over days or years, rather than in the short-run of an experiment. This observation implies that multiple-trial laboratory experiments may not provide economic agents with the necessary experience to significantly influence the endowment effect.

To provide a strict test of whether market/trading experience influences the endowment effect, I follow Knetsch (1989) and Kahneman et al. (1990) and use a straightforward random allocation design with two treatments. In one treatment the subject is endowed with good A and has the option to trade it for good B. In a second treatment, a different subject is endowed with good B and has the option to trade it for good A. Since subjects are allocated to one of the two treatments randomly, fewer than $50 \%$ of the subjects should swap their good if an endowment effect exists. Alternatively, if an endowment effect does not exist, approximately $50 \%$ of the subjects should trade their good. In Knetsch (1989), the evidence in favor of the endowment effect is sharp, as $89 \%$ of those originally endowed with a mug chose to keep the mug, and $90 \%$ of those endowed with a chocolate bar decided to keep the chocolate bar. Results are equally as convincing in Kahneman et al. (1990), where 11 subjects should have traded their Cornell University coffee mugs, but only 3 trades were observed over 4 repetitions. Under any interpretation, both pieces of evidence are convincing that an endowment effect exists. 
My test of the endowment effect departs from previous studies by examining subjects' propensity to trade unique consumable items in a well-functioning marketplace-on the floor of a sportscard show. Good A, a Kansas City Royals game ticket stub dated June 14, 1996, was issued for admission to the baseball game in which Cal Ripken Jr. broke the world record for consecutive games played. Good B, a dated certificate commemorating the game that Nolan Ryan achieved what only 20 previous baseball players had done, winning 300 games (dated July 31, 1990), was distributed by the Milwaukee Brewers to fans in attendance of the ballgame. I was fortunate enough to obtain these two unique pieces of sports memorabilia in quantity because I personally attended both events. ${ }^{4}$

The field experiments, which were conducted in December 1999 at a sportscard show in Orlando, FL, are most similar in methodology to those of John A. List (2000) and John A. List and David Lucking-Reilly (2000) who use sportscard show experiments to examine issues associated with contingent valuation and demand reduction in multiunit uniform price auctions. Field experiments present a tradeoff: they give up some of the controls of a laboratory experiment (such as induced valuations) in exchange for increased realism. The current experiments match the real-world settings which economic theory attempts to explain: the traders compete for real goods rather than explicit cash values, they are not told explicitly the distributions of other's valuations, and they are likely to have previous experience trading related goods. Although field experiments are not quotidian in the economics literature, they do provide a useful middle

\footnotetext{
${ }^{4}$ Sports memorabilia has many favorable characteristics for a WTA/WTP exercise including familiarity, the ability to deliver, and an abstract quality beyond the normal market good (List and Shogren, 1998a).
} 
ground between the tight controls of the laboratory and the vagaries of completely uncontrolled field data.

Each participant's experience typically followed three steps: (1) completing a survey, (2) considering the potential trade, and (3) conclusion of the transaction and exit interview. In Step 1, the administrator approached potential subjects entering the trading card show and inquired about their interest in filling out a survey that would take about five minutes. ${ }^{5}$ If the individual agreed, the monitor briefly explained that in return for completing the survey the subject would receive good A (or good B), where good A (good B) was the Ripken ticket stub (Ryan certificate). After physically giving the subject either good A or B, the subject proceeded to fill out the survey. The monitor worked one-on-one with the participant and no time limit was imposed.

In Step 2, the administrator retrieved the other good from under the dealer table and informed the subject that she had the opportunity to trade good A for good B, or vice versa. The monitor allowed the subject to inspect both goods; after which the subject either consummated a trade or kept the original good. Step 3 closed the experiment and included an exit interview asking the subject if she planned to keep the good for her own collection. In the nondealer experiments, the good type was changed at the top of each hour, so subjects' treatment type was determined based on the time they visited the table at the card show. The dealer treatments took place in the same fashion as the nondealer treatments, with one exception. Instead of waiting for participants to arrive at the monitor's table, the administrator visited each dealer at his/her booth before the sportscard show opened, alternating the endowed good. The nondealer treatments took

\footnotetext{
${ }^{5}$ The survey is contained in Appendix A.
} 
approximately six hours to complete (12pm to $6 \mathrm{pm}$ on Saturday), while the dealer treatments took about two hours (7am to 9am on Saturday). No subjects participated in more than one treatment.

A few noteworthy aspects of the experimental design merit further consideration. First, note that subjects received the good as payment for completing the survey, and had the good in their possession while filling out the survey. These two attributes have been found to strengthen the endowment effect. Second, when performing this type of trading exercise, care should be taken to select goods of approximately equal value to avoid a result of everyone selecting one type of good. Since the memorabilia items used in this study are unique and not typically bought and sold on the sports memorabilia market, there was little guidance on the market value of either good. In a market pre-test at a 1998 Orlando trading card show, I asked fifty dealer and nondealer subjects to hypothetically choose one of the two items. Twenty-seven chose the Ripken ticket, whereas twenty-three chose the Ryan certificate. I therefore concluded that the goods where similar enough in value to use for a trading exercise.

Third, I was careful in choosing the goods to assure they would actually be consumed by the individual, rather than put up for trade or sale immediately after the transaction. During the exit interview, more than $95 \%$ of the subjects stated that they planned to consume the piece of memorabilia (e.g., keep it for their own collection). ${ }^{6}$ Finally, the uniqueness of the two goods (only a few subjects had previously seen either

\footnotetext{
6 This is potentially important because some evidence suggests WTA and WTP are roughly equivalent for securities-Kahneman et al. (1990, p. 1328) note that "there are some cases in which no endowment effect would be expected, such as when goods are purchased for resale rather than for utilization." One explanation for this conjecture is that subjects dealing with resale goods do not allow themselves to get "attached to the good" because it will soon leave their portfolio. If one believes that dealers do not get as attached to sports memorabilia as nondealers, the data herein represent a first test of such an effect.
} 
piece of memorabilia before the experiment) guaranteed that the subject had not previously dealt with either piece of memorabilia. The test herein is therefore different from previous studies of market experience where the good is identical across multiple rounds of a laboratory experiment. Rather, the treatments in this experimental design allow a test of whether the level of market or trading experience with related goods affects the WTA/WTP disparity.

Table 1 provides a statistical description of the subject characteristics in each subgroup. In total, I observed the trading decisions across 148 subjects- 74 dealers and 74 nondealers. Sample sizes in List (2000) and List and Lucking-Reilly (2000) are similar. Central tendencies of the variables reveal that dealers are much more active in trading cards and sports memorabilia, and have had more years of experience in the sportscard and memorabilia market. Sample statistics for the other variables are broadly consistent with previous studies and suggest that the two subgroups are similar in important demographic characteristics.

\section{Experimental Results}

A quick summary of the empirical results is that consistent with the bulk of past experimental evidence, there are signs of a significant endowment effect in the aggregate data as fewer trades were executed than neoclassical theory would predict. This dysfunctionality, however, is not evident for consumers that have significant trading experience. Across all consumer types, I find that trading experience and the endowment effect are negatively related. In addition, within the group of subjects that had intense trading experience, the endowment effect essentially disappears. These and other empirical findings are described more fully below. The general analysis will proceed by 
examining the field data and when behavior differs across groups of subjects, I analyze whether intensity of trading experience, general market experience, or other demographic factors might be responsible for the behavioral differences.

\section{An Endowment Effect is Evident}

The top panel of Table 2 reports summary statistics of the pooled data. Most importantly, statistics in the pooled sample suggest undertrading occurred. Given that subjects were randomly allocated either good A (Ripken ticket) or good B (Ryan certificate), equivalence of WTA and WTP would imply that approximately half of the goods were improperly allocated and should be traded. The actual percentages of subjects who chose to trade are $32.8 \%$ and $34.6 \%$, suggesting that WTA $>$ WTP. These figures suggest that once endowed with one of the goods the subjects were close to two times more likely to select that good (computed as _ $\left(\left(\mathrm{P}_{\mathrm{A} \mid \mathrm{A}} / \mathrm{P}_{\mathrm{A} \mid \mathrm{B}}\right)+\left(\mathrm{P}_{\mathrm{B} \mid \mathrm{B}} / \mathrm{P}_{\mathrm{B} \mid \mathrm{A}}\right)\right)$.

Although these results are suggestive, they may be an artifact of the sampling procedure-by chance subjects who preferred good A (good B) may have been endowed with good A (good B), leading to false inference. To amend this situation, I test the null hypothesis of no endowment effect by using a Fisher's exact test, which has a hypergeometric distribution under the null. The result of the exact test presented in row 1, column 2 of Table 2 strongly suggests that the null hypothesis should be rejected at $\mathrm{p}<$ .001 for the pooled sample, implying that an endowment effect exists. This evidence, which is consistent with past experimental studies, is at odds with conventional economic theory, which assumes that indifference curves are completely reversible (see Knetsch, 1989). 


\section{A Link Exists Between the Endowment Effect and Trading Experience}

Panels two and three in Table 2 present dealer and nondealer split subsamples and tell an intuitive story consistent with the maintained hypothesis-dealers tend to trade more than nondealers, regardless of which good they were initially endowed. For example, whereas $43.6 \%$ and $45.7 \%$ of dealers chose to execute a trade, only $20 \%-25 \%$ of nondealers traded their endowed good. These proportions suggest that nondealers were nearly 3.5 times more likely to select the good which they were endowed, whereas dealers were only 1.25 times more likely to choose their endowed good. A Fisher's Exact test shows that for nondealers the null hypothesis of no endowment effect should be rejected at the $\mathrm{p}<.001$ level. Alternatively, the null hypothesis cannot be rejected at conventional significance levels in the dealer treatments. This result provides initial evidence that experienced consumers' utility functions may be void of an important attribute that tends to induce an endowment effect.

Given that Table 1 indicates the average number of trades (cards or memorabilia) executed in a typical month by dealers (nondealers) is 14.80 (5.66), it is quite possible that dealers have developed a knowledge of carrying out profitable trades, whereas some nondealers have not learned about the beneficial aspects of trading. ${ }^{7}$ In this sense, one explanation of the results in Table 2 is that dealers have trading experience with closely related goods that spills-over to this new environment. Accordingly, a "rationality spillover" could be responsible for inducing the disappearance of the endowment effect for the dealers. If this premise is correct, a subgroup of nondealers with intense trading experience may show signs of little or no endowment effect.

\footnotetext{
${ }^{7}$ Broadly interpreted, Y.P. Chu and R.L. Chu (1990) find a parallel result in a much different laboratory setting.
} 
Table 3 provides a breakdown of the nondealer data based on the level of trading experience of each subject. I split the sample of experienced and inexperienced nondealers according to the central tendency of the data. Experienced nondealers are those that trade 6 or more times in a typical month, where 6 is a shade above the mean level of monthly trades of 5.66. Inexperienced nondealers are those subjects that trade less than 6 times per month. The results are compelling. For experienced nondealers, $46.7 \%$ opted to trade. This figure is very close to the dealers' trading strategy observed above and using a Fisher's exact test I find that the null hypothesis (of no endowment effect) cannot be rejected at conventional significance levels $(p=0.28)$. For inexperienced nondealers the endowment effect is relatively large-only $6.8 \%$ of subjects opted to trade, and the hypothesis of no endowment effect is strongly rejected ( $\mathrm{p}<$ 0.001). This latter finding suggests that once inexperienced consumers are endowed with a good, they are 13 times more likely to keep that good. This average increase in the likelihood that the subject chooses a good once endowed with it is slightly higher than that observed in Knetsch (1989).

Although the analysis of the raw data provides evidence that supports the main conjecture of the study, there has been no attempt to control for other factors that may affect the propensity to trade. These other subject-specific factors, which include years of trading experience, gender, income, education, and age can be adequately accounted for in a well-specified econometric model. To condition on these factors, I estimate the following logit model:

$$
\text { trade }=\mathrm{g}(\alpha+\beta X),
$$


where trade equals 1 if a trade was executed, 0 otherwise; $\mathrm{g}(\bullet)=1 /\left(1+\mathrm{e}^{-\mathrm{x}}\right)$ is the standard logit function; $X$ includes subject-specific variables that may affect the propensity to trade. Variables in $X$ are listed in Table 1 and include the number of trades in a typical month, years of trading experience, yearly income, age, gender, education, and a dichotomous variable indicating whether the subject was endowed with Good B. Also included in $X$ are interaction terms that allow the trade function to vary across dealers and nondealers. Equation (1) therefore tests whether trading experience influences trading rates, ceteris paribus, and whether this effect is heterogeneous across subject groups.

Summary estimates of equation (1) are presented in Table 4; Appendix B provides parameter estimates by subgroup to facilitate comparison. I include both ordinary least squares regression estimates as well as empirical estimates from logit models. Regardless of estimation technique, coefficient estimates of trading experience in Table 4 suggest that the propensity to trade and trading experience are positively related. For nondealers, the logit coefficient estimate of 0.13 is significantly different from zero at the $\mathrm{p}<.01$ level, suggesting experience with trading similar items has a positive influence on the propensity to trade. Alternatively, the effect of trading experience for dealers is considerably weaker, $0.03(0.13-0.10)$, and is statistically different from the nondealer trading experience coefficient estimate at the $\mathrm{p}<.09$ level. This result may suggest that some dealers have had substantial opportunity to interact in a market setting, rendering the marginal impact of another trade less important. Nevertheless, coefficient estimates from both models suggest that experience in trading related items has an important influence in shaping the endowment effect across all consumer types. 
Interestingly, experience, as measured by the number of years in the sportscard market, is not a significant factor in the trading decision for either subsample. This result suggests that the endowment effect is not related to the number of years the subject has had in the market. This finding is consistent with the experimental results in Kahneman et al. (1990). Many of the other coefficient estimates are also not significantly different from zero at conventional levels. Taken as a whole, parameter estimates from both regression models imply that the only significant influence on the propensity to trade is the level of trading experience. This finding supports the unconditional results presented above and suggests the WTA/WTP disparity may critically depend on the nature and intensity of the consumer's experience level. ${ }^{8}$

The overall pattern of observed results is consistent with Charles Kolstad and Rolando Guzman's (1999) theoretic bidding model in which subjects have private values, but know them imperfectly. In their model, which includes both informed and uninformed bidders, an increase in the level of individual information decreases the gap between WTP and WTA. In addition, as the cost of information increases, the expected gap between WTP and WTA increases. Coupling the intuition of these two insights yields their Proposition 7 (p. 77), which aptly describes my experimental findings: "In a private value, costly information rational expectations equilibrium, with information costs such that there are informed and uninformed bidders, a mean-increasing shift in the distribution of information costs results in a decrease in the number of potential trades."

\footnotetext{
${ }^{8}$ Although the field results are consistent with my own experiences in the sportscard market, it remains an open question as to whether experienced consumers have no WTA/WTP disparity because of experience (treatment), or because of a prior disposition toward having no such gap leads them to trade more often (selection). Future work using panel data can sort out this issue. I thank Colin Camerer for pointing out this interpretive question.
} 
This conjecture, that the number of trades and the number of informed bidders are directly related, lends theoretical structure to the empirical findings herein.

\section{Conclusions}

Whether preferences are defined over consumption levels or changes in consumption merits serious consideration. If preferences are defined over changes in consumption, a re-evaluation of a good deal of economic analysis is necessary since the basic independence assumption, which is used in most theoretical and applied economic models to assess the operation of markets, is directly refuted. The current literature provides substantial evidence that a nontrivial gap exists between WTA and WTP, making a strong case against some closely held economic doctrines. Some commentators, however, have argued that the observed discrepancy in WTA and WTP values may merely be a mistake made by inexperienced consumers and through time these consumers will learn and be more inclined to take part in beneficial trades. Although previous literature has indirectly tested this premise by examining subject behavior in multiple-trial experiments, the intensity of market trading experience at the individual level may go well beyond what subjects could possibly learn in multiple-shot laboratory experiments.

In this study I return to the field and examine whether trading experience affects the individual's propensity to execute a trade. Examining trading patterns on the floor of a sportscard show yields two unique insights. First, the field data suggest there is an overall endowment effect-I find that significantly less than $50 \%$ of subjects actually traded their endowed good, even though standard neoclassical theory predictions imply that $50 \%$ should trade. Second, I find strong evidence that individual trading experience 
matters. Across all consumer types trading experience and the endowment effect are negatively related. Furthermore, within the group of subjects that had intense trading experience (sportscard dealers and experienced nondealers), the endowment effect essentially disappears.

These results provide initial evidence consistent with the notion that market experience has a great deal of significance in shaping the WTA/WTP disparity. Although value disparities are still evident for intense consumers, the wedge between WTA and WTP is substantially reduced for consumers with substantial trading experience. These results uncover important successes and failures of the theoretical literature, and provide challenges for both neoclassical and reference-dependent theorists. 


\section{References}

Brookshire, David, Randall, Alan, and Stoll, John R. "Value Increments and Decrements in Natural Resource Service Flows," American Journal of Agricultural Economics 1980, 62(3), pp. 185-193.

Brookshire, David and Coursey, Don. "Measuring the Value of a Public Good: An Empirical Comparison of Elicitation Procedures," American Economic Review, September 1987, 77(4), pp. 554-566.

Camerer, Colin F. and Hogarth, Robin M. "The Effects of Financial Incentives in Experiments: A Review and Capital-Labor-Production Framework," Journal of Risk and Uncertainty, 1999, 19, pp. 7-42.

Chu, Y.P. and Chu, R.L. "The Subsidence of Preference Reversals in Simplified and Marketlike Experimental Settings: A Note," American Economic Review, September 1990, 80(4), pp. 902-911.

Coursey, Don, Hovis, John, and Schulze, William. “The Disparity Between Willingness to Accept and Willingness to Pay Measures of Value." Quarterly Journal of Economics, 1987, 102(3), pp. 679-90.

Grether, David M., "Individual Behavior and Market Performance" American Journal of Agricultural Economics 1994, 76, pp. 1079-1083.

Hanemann, W. Michael. "Willingness to Pay and Willingness to Accept: How Much Can They Differ?" American Economic Review, June 1991, 81(3), pp. 635-647.

Heiner, Ronald. "The Origin of Predictable Behavior," American Economic Review, September 1983, 73(4), pp. 560-595. 
Hoffman, Elizabeth and Spitzer, Matthew. "Willingness to Pay vs. Willingness to Accept: Legal and Economic Implications," Washington University Law Quarterly, 1993, 71(1), pp. 59-114.

Horowitz, John K. and McConnell, K.E. "A Review of WTA/WTP Studies,” Working paper, University of Maryland, 1998.

Kahneman, Daniel, Knetsch, Jack L., and Thaler, Richard H. "Experimental Tests of the Endowment Effect and the Coase Theorem." Journal of Political Economy, December 1990, 98(6), pp. 1325-48.

Kahneman, Daniel and Tversky, Amos. "Prospect Theory: An Analysis of Decision Under Risk,” Econometrica, 1979, 47(2), pp. 263-291.

Knetsch, Jack L. "The Endowment Effect and Evidence of Nonreversible Indifference Curves," American Economic Review, December 1989, 79(5), pp. 1277-1284.

Knetsch, Jack L. and J.A. Sinden. “The Persistence of Evaluation Disparities,” Quarterly Journal of Economics, 1987, 102(3), pp. 691-695.

Knetsch, Jack L., Fang-Fang Tang, and Thaler, Richard H. "The Endowment Effect and repeated Market Trials: Is the Vickrey Auction Demand Revealing?" Working paper, Simon Fraser University, 1998.

Knez, Peter, Smith, Vernon L., and Williams, Arlington. "Individual Rationality, Market Rationality, and Value Estimation," American Economic Review, May 1985, 75(2), pp. 397-402.

Kolstad, Charles and Guzman, Rolando. "Information and the Divergence between Willingness to Accept and Willingness to Pay," Journal of Environmental Economics and Management," July 1999, 38(1), pp. 66-80 
List, John A. "Do Explicit Warnings Eliminate the Hypothetical Bias in Elicitation Procedures? Evidence from Field Auctions for Sportscards.” American Economic Review, forthcoming.

List, John A. and Lucking-Reilly, David. "Demand Reduction in Multi-Unit Auctions: Evidence from a Sportscard Field Experiment." American Economic Review, forthcoming.

List, John A. and Shogren, Jason F. "Calibration of the Difference Between Actual and Hypothetical Valuations in a Field Experiment." Journal of Economic Behavior and Organization, 1998a, 37(2), pp. 193-205.

List, John A. and Shogren, Jason F. "The Deadweight Loss of Christmas: Comment." American Economic Review, 1998b, 88(5), pp. 1350-1355.

Loomes, Graham and Sugden, Robert. "Regret Theory: An Alternative Theory of Rational Choice Under Uncertainty," Economic Journal, 1982, 92(3), pp. 805824.

Randall, Alan and Stoll, John R. "Consumer's Surplus in Commodity Space." American Economic Review, June 1980, 71(3), pp. 449-57.

Shogren, Jason F., Shin, Seung Y., Hayes, Dermot J., and Kliebenstein, James B. "Resolving Differences in Willingness to Pay and Willingness to Accept." American Economic Review, March 1994, 84(1), pp. 255-70.

Thaler, Richard. "Toward a Positive Theory of Consumer Choice," Journal of Economic Behavior and Organization, 1980, 1, pp. 39-60. 
Tversky, Amos and Kahneman, Daniel. "Loss Aversion in Riskless Choice: A ReferenceDependent Model," Quarterly Journal of Economics, 1991, 106(4), pp. 10391061.

Willig, Robert. "Consumer's Surplus Without Apology." American Economic Review, September 1976, 66(4), pp. 589-97. 


\begin{tabular}{lcc} 
& $\begin{array}{c}\text { Dealers } \\
\text { Mean } \\
\text { (Std. Dev.) }\end{array}$ & $\begin{array}{c}\text { Nondealers } \\
\text { Mean } \\
\text { (Std. Dev.) }\end{array}$ \\
\hline Trading Experience & 14.80 & 5.66 \\
& $(11.0)$ & $(6.62)$ \\
Years of Market & 10.36 & 6.95 \\
Experience & $(6.75)$ & $(9.37)$ \\
Income & 4.26 & 4.04 \\
& $(1.92)$ & $(2.06)$ \\
Age & 34.68 & 34.70 \\
& $(11.98)$ & $(14.06)$ \\
Gender (\%male) & 0.93 & 0.86 \\
& $(0.25)$ & $(0.34)$ \\
Education & 3.42 & 3.84 \\
& $(1.42)$ & $(1.49)$ \\
Good B & 0.527 & 0.527 \\
& $(0.50)$ & $(0.50)$ \\
$n$ & & \\
& & \\
& & \\
& &
\end{tabular}

Notes:

1. Trading experience represents the number of trades made in a typical month.

2. Years of market experience denotes years that the subject has been active on the sportscard market.

3. Income denotes categorical variable (1-8): 1) Less than $\$ 10,000,2) \$ 10,000$ to $\$ 19,999,3$ ) $\$ 20,000$ to $\$ 29,999,4) \$ 30,000$ to $\$ 39,999,5) \$ 40,000$ to $\$ 49,999,6) \$ 50,000$ to $\$ 74,999,7$ ) $\$ 75,000$ to $\$ 99,999$ 8) $\$ 100,000$ or over.

4. Age denotes actual age in years.

5. Gender denotes categorical variable: 0 if female, 1 if male.

6. Education denotes categorical variable 1) Eighth grade or less, 2) High School 3) 2-Year College, 4) Other Post-High School, 5) 4-Year College, 6) Graduate School Education.

7. Good $B$ denotes the subject's initial endowment, and $=1$ if the subject was endowed with Good B, 0 otherwise. 


\begin{tabular}{lcc} 
Variable & \% Traded & $\begin{array}{c}\text { p-value for } \\
\text { Fisher's exact test }\end{array}$ \\
\hline
\end{tabular}

Pooled sample $(\mathrm{n}=148)$

Good A for Good B $\quad 32.8 \quad 0.001$

Good B for Good A $\quad 34.6$

Dealers $(\mathrm{n}=74)$

Good A for Good B $\quad 45.7 \quad 0.122$

Good B for Good A $\quad 43.6$

Nondealers $(\mathrm{n}=74)$

Good A for Good B $\quad 20.0 \quad 0.001$

Good B for Good A $\quad 25.6$

Notes:

1. Good A is a Cal Ripken Jr. game ticket stub, circa 1996. Good B is a Nolan Ryan certificate, circa 1990.

2. Fisher's exact test has a null hypothesis of no endowment effect. 


\begin{tabular}{lcc} 
Variable & \% Traded & $\begin{array}{c}\text { p-value for } \\
\text { Fisher's exact test }\end{array}$ \\
\hline $\begin{array}{l}\text { Experienced } \\
\text { nondealers }(\mathrm{n}=30)\end{array}$ & 46.7 & 0.28 \\
$\begin{array}{l}\text { Inexperienced } \\
\text { nondealers }(\mathrm{n}=44)\end{array}$ & 6.80 & 0.001 \\
\hline
\end{tabular}

Notes:

1. Experienced nondealers are those consumers that trade 6 or more times per month (5.66 is the mean level of monthly trades for nondealers). Inexperienced nondealers trade less than 6 times per month.

2. Fisher's exact test has a null hypothesis of no endowment effect. 
Table 4 Estimation Results for Trade Function

\begin{tabular}{|c|c|c|}
\hline Variable & $\begin{array}{c}\text { OLS } \\
\text { Trade Function } \\
\end{array}$ & $\begin{array}{c}\text { Logit } \\
\text { Trade Function } \\
\end{array}$ \\
\hline Constant & $\begin{array}{l}-0.18 \\
(0.23)\end{array}$ & $\begin{array}{l}-4.29 * \\
(1.84)\end{array}$ \\
\hline Dealer & $\begin{array}{c}0.55 \\
(0.37)\end{array}$ & $\begin{array}{l}3.71 * \\
(2.20)\end{array}$ \\
\hline $\begin{array}{l}\text { Trading } \\
\text { Experience }\end{array}$ & $\begin{array}{l}0.02 * * \\
(0.008)\end{array}$ & $\begin{array}{l}0.13 * * \\
(0.05)\end{array}$ \\
\hline $\begin{array}{l}\text { Trading Experience } \\
\text { *Dealer }\end{array}$ & $\begin{array}{l}-0.016 \\
(0.01)\end{array}$ & $\begin{array}{l}-0.10^{*} \\
(0.06)\end{array}$ \\
\hline $\begin{array}{l}\text { Years of Market } \\
\text { Experience }\end{array}$ & $\begin{array}{l}-0.001 \\
(0.006)\end{array}$ & $\begin{array}{l}-0.001 \\
(0.04)\end{array}$ \\
\hline $\begin{array}{l}\text { Years of Market } \\
\text { Experience*Dealer }\end{array}$ & $\begin{array}{l}-0.008 \\
(0.01)\end{array}$ & $\begin{array}{l}-0.04 \\
(0.06)\end{array}$ \\
\hline Income & $\begin{array}{c}0.03 \\
(0.03)\end{array}$ & $\begin{array}{c}0.19 \\
(0.21)\end{array}$ \\
\hline Income*Dealer & $\begin{array}{l}-0.09^{*} \\
(0.05)\end{array}$ & $\begin{array}{l}-0.47^{*} \\
(0.27)\end{array}$ \\
\hline Age & $\begin{array}{l}-0.001 \\
(0.005)\end{array}$ & $\begin{array}{l}-0.002 \\
(0.03)\end{array}$ \\
\hline Age* Dealer & $\begin{array}{c}0.002 \\
(0.008)\end{array}$ & $\begin{array}{c}0.01 \\
(0.04)\end{array}$ \\
\hline Gender & $\begin{array}{c}0.19 \\
(0.14)\end{array}$ & $\begin{array}{c}1.59 \\
(1.29)\end{array}$ \\
\hline Gender*Dealer & $\begin{array}{l}-0.13 \\
(0.27)\end{array}$ & $\begin{array}{l}-1.29 \\
(1.64)\end{array}$ \\
\hline Education & $\begin{array}{l}0.001 \\
(0.04)\end{array}$ & $\begin{array}{l}-0.006 \\
(0.22)\end{array}$ \\
\hline Education*Dealer & $\begin{array}{c}0.07 \\
(0.06)\end{array}$ & $\begin{array}{c}0.31 \\
(0.30)\end{array}$ \\
\hline
\end{tabular}


Table 4, Continued

Good B $\quad 0.03$

(0.11)

$-0.09$

(0.16)

$R^{2}$

0.16

148
0.13

$(0.70)$

$-0.43$

(0.86)

148

Notes:

1. Dependent variable equals 1 if subject chose to trade, 0 otherwise. Gender $=1$ if male, 0 otherwise; Good B = 1 if subject was endowed with Good B, 0 otherwise.

2. Dealer $=1$ if dealer, 0 if not.

3. Standard errors are in parentheses beneath coefficient estimates. Parameter estimates in column 2 are logit coefficients.

4. ${ }^{* *}$ Denotes coefficient estimate is significant at the $\mathrm{p}<.01$ level. $*$ Denotes coefficient estimate is significant at the $\mathrm{p}<.10$ level. 
These questions will be used for statistical purposes only. THIS INFORMATION WILL BE KEPT STRICTLY CONFIDENTIAL AND WILL BE DESTROYED UPON COMPLETION OF THE STUDY.

1. How long have you been active in the sportscards and memorabilia market? yrs

2. Approximately how many trades (cards or memorabilia) do you make in a typical month? - Note that trades could include pokemon cards, sportscards, other trading cards, and sports memorabilia.

3. Are you a sportscard or sports memorabilia professional dealer?

4. Gender: 1) Male 2) Female

5. Age Date of Birth

6. What is the highest grade of education that you have completed. (Circle one)
1) Eighth grade 3) 2-Year College
5) 4-Year College
2) High School 4) Other Post-High School
6) Graduate School Education

7. What is your approximate yearly income from all sources, before taxes?
1) Less than $\$ 10,000$
5) $\$ 40,000$ to $\$ 49,999$
2) $\$ 10,000$ to $\$ 19,999$
6) $\$ 50,000$ to $\$ 74,999$
3) $\$ 20,000$ to $\$ 29,999$
7) $\$ 75,000$ to $\$ 99,999$
4) $\$ 30,000$ to $\$ 39,999$
8) $\$ 100,000$ or over

8. Have you ever seen the piece of memorabilia that I gave you? 


\begin{tabular}{|c|c|c|c|c|}
\hline \multirow[b]{2}{*}{ Variable } & \multicolumn{2}{|c|}{$\underline{\text { Dealers }}$} & \multicolumn{2}{|c|}{ Nondealers } \\
\hline & $\begin{array}{c}\text { OLS } \\
\text { Trade Function } \\
\end{array}$ & $\begin{array}{c}\text { Logit } \\
\text { Trade Function } \\
\end{array}$ & $\begin{array}{c}\text { OLS } \\
\text { Trade Function } \\
\end{array}$ & $\begin{array}{c}\text { Logit } \\
\text { Trade Function } \\
\end{array}$ \\
\hline Constant & $\begin{array}{c}0.36 \\
(0.29)\end{array}$ & $\begin{array}{l}-0.58 \\
(1.20)\end{array}$ & $\begin{array}{l}-0.18 \\
(0.23)\end{array}$ & $\begin{array}{c}-4.29 * * \\
(1.84)\end{array}$ \\
\hline $\begin{array}{l}\text { Trading } \\
\text { Experience }\end{array}$ & $\begin{array}{c}0.008 \\
(0.005)\end{array}$ & $\begin{array}{c}0.03 \\
(0.02)\end{array}$ & $\begin{array}{l}0.02 * * \\
(0.008)\end{array}$ & $\begin{array}{c}0.13 * * \\
(0.05)\end{array}$ \\
\hline $\begin{array}{l}\text { Years of Mc } \\
\text { Experience }\end{array}$ & $\begin{array}{r}\text { arket }-0.008 \\
(0.009)\end{array}$ & $\begin{array}{l}-0.04 \\
(0.04)\end{array}$ & $\begin{array}{l}-0.001 \\
(0.006)\end{array}$ & $\begin{array}{l}-0.001 \\
(0.04)\end{array}$ \\
\hline Income & $\begin{array}{l}-0.06 \\
(0.04)\end{array}$ & $\begin{array}{l}-0.28 \\
(0.18)\end{array}$ & $\begin{array}{c}0.03 \\
(0.03)\end{array}$ & $\begin{array}{c}0.19 \\
(0.21)\end{array}$ \\
\hline Age & $\begin{array}{c}0.002 \\
(0.006)\end{array}$ & $\begin{array}{l}0.008 \\
(0.03)\end{array}$ & $\begin{array}{l}-0.001 \\
(0.005)\end{array}$ & $\begin{array}{l}0.002 \\
(0.03)\end{array}$ \\
\hline Gender & $\begin{array}{c}0.06 \\
(0.24)\end{array}$ & $\begin{array}{c}0.30 \\
(1.01)\end{array}$ & $\begin{array}{c}0.19 \\
(0.14)\end{array}$ & $\begin{array}{c}1.59 \\
(1.29)\end{array}$ \\
\hline Education & $\begin{array}{c}0.06 \\
(0.05)\end{array}$ & $\begin{array}{c}0.30 \\
(0.21)\end{array}$ & $\begin{array}{l}0.007 \\
(0.04)\end{array}$ & $\begin{array}{l}-0.006 \\
(0.21)\end{array}$ \\
\hline Good B & $\begin{array}{l}-0.07 \\
(0.11)\end{array}$ & $\begin{array}{l}-0.30 \\
(0.51)\end{array}$ & $\begin{array}{c}0.03 \\
(0.11)\end{array}$ & $\begin{array}{c}0.13 \\
(0.70)\end{array}$ \\
\hline$R^{2}$ & 0.10 & --- & 0.14 & --- \\
\hline$N$ & 74 & 74 & 74 & 74 \\
\hline
\end{tabular}

Notes:

1. Dependent variable equals 1 if subject chose to trade, 0 otherwise. Gender $=1$ if male, 0 otherwise; Good B = 1 if subject was endowed with Good B, 0 otherwise.

2. Standard errors are in parentheses beneath coefficient estimates. Parameter estimates in columns 2 and 4 are logit coefficients.

3. **Denotes coefficient estimate is significant at the $\mathrm{p}<.01$ level. 